ISSN 1823-626X

Journal of Fundamental Sciences

available online at http://jfs.ibnusina.utm.my

\title{
Determination of Lewis and Brönsted acid sites by gas flow-injection technique
}

Malik Musthofa ${ }^{1}$, Ainul Hakimah Karim ${ }^{1}$, Nurrulhidayah Ahmad Fadzlillaah ${ }^{1}$, Nur Hazirah Rozali Annuar ${ }^{1}$, Aishah Abdul Jalil ${ }^{2}$, Sugeng Triwahyono ${ }^{1 *}$

${ }^{1}$ Ibnu Sina Institute for Fundamental Science Studies, ${ }^{2}$ Department. of Chemical Engineering, Faculty of Chemical Engineering

Universiti Teknologi Malaysia, 81310 UTM Johor Bahru, Johor, Malaysia

Received 26 February 2010, Revised 7 June 2010, Accepted 29 June 2010, Available online 6 October 2010

\begin{abstract}
Gas flow-injection technique pyridine-FTIR was studied for determination of Lewis and Brönsted acid sites on the solid super acid catalysts. The system consists of stainless steel gas cell which can be heated up to $623 \mathrm{~K}, \mathrm{CaF} 2$ windows, pyridine injection port and double liquid nitrogen trap for removal of moisture. Pure nitrogen gas and pyridine were used as a carrier and probe molecule. Pyridine was injected to the sysem at $423 \mathrm{~K}$ followed by flushing of $\mathrm{N}_{2}$ gas through double liquid nitrogen trap at 423 for $1 \mathrm{~h}$ and at $573 \mathrm{~K}$ for $30 \mathrm{~min}$. All spectra were recorded at room temperature. This technique gave similar results to those of taken by vacuum system for $\mathrm{HZSM}-5, \mathrm{Pt} / \mathrm{SO}_{4}{ }^{2-}-\mathrm{ZrO}_{2}, \mathrm{Al}_{2} \mathrm{O}_{3}$ catalysts.
\end{abstract}

| Gas flow technique | Pyridine | Lewis acid sites | Brönsted acid sites | HZSM-5 | Pt/ $\mathrm{SO}_{4}{ }^{2-}-\mathrm{ZrO}_{2} \mid \mathrm{Al}_{2} \mathrm{O}_{3}$ |

(R) 2010 Ibnu Sina Institute. All rights reserved. http://dx.doi.org/10.11113/mjfas.v6n2.195

\section{INTRODUCTION}

Solid acid catalysts have found significant role on the development of more efficient and environmentally friendly chemical technologies [1]. Measurement of their surface acidity therefore is of great interest. Several techniques have been proposed to provide information on the type and acidity of solid catalysts for more understanding in the properties of solid catalyst. Among these techniques, conventional pyridine infrared spectroscopy is the easiest and most direct method to identify the Lewis and Bronsted acid of solid catalysts [2-6].

Since the large application and the experimental reasons, in situ apparatus of IR spectroscopy of pyridine adsorption was successfully extensively developed. However, this technique apparatus is commonly designed for vacuum system which needs critical skills and equipments as well the long time analysis [7]. Consequently, flow technique of IR spectroscopy of pyridine adsorption was suggested as more simple technique apparatus which allow the work was performed more efficiently. Although this technique was applied by some researchers [8-9], the detail investigation of this technique compared to vacuum one is still lack. In the present paper, we report the results of flow system IR of pyridine adsorption to determine the Bronsted and Lewis acid sites on solid acid catalysts.

Corresponding author at: Ibnu Sina Institute for Fundamental Science Studies Universiti Teknologi Malaysia, 81310 UTM Johor Bahru, Johor, Malaysia E-mail address: sugeng@ibnusina.utm.my (Sugeng Triwahyono)

\section{EXPERIMENTAL}

\subsection{Preparation of catalyst}

A commercial HZSM-5 (Zeolyst) with $\mathrm{Si} / \mathrm{Al}$ atomic ratio of 80 was used as a zeolitic sample. The HZSM-5 contains only protonic acid sites after treatment at $773 \mathrm{~K}$. The sulfate ion-treated $\mathrm{Zr}(\mathrm{OH})_{4}$ sample was prepared by impregnation of $\mathrm{Zr}(\mathrm{OH})_{4}$ (Aldrich) with $1 \mathrm{~N}$ $\mathrm{H}_{2} \mathrm{SO}_{4}$ (Merck) aqueous solution, followed by filtration and drying at $383 \mathrm{~K}$ overnight. The sulfated zirconia, $\mathrm{SO}_{4}{ }^{2-}$ $\mathrm{ZrO}_{2}$ was obtained by calcinations of $\mathrm{SO}_{4}{ }^{2-} \mathrm{Zr}(\mathrm{OH})_{4}$ at 873 $\mathrm{K}$ for $3 \mathrm{~h}$ in air. The $\mathrm{Pt} / \mathrm{SO}_{4}{ }^{2-}-\mathrm{ZrO}_{2}$ was prepared by impregnation of the $\mathrm{SO}_{4}{ }^{2-}-\mathrm{ZrO}_{2}$ with an aqueous solution of $\mathrm{H}_{2} \mathrm{PtCl}_{6}$, (Merck) followed by calcinations at $873 \mathrm{~K}$ for $3 \mathrm{~h}$ in air. The content of $\mathrm{Pt}$ was $0.5 \mathrm{wt} \%$.

\subsection{Characterization of catalyst}

The crystalline structure of samples were determined with a Bruker AXS D8 Automatic Powder Diffractometer using $\mathrm{Cu} \mathrm{K} \alpha$ radiation with $\lambda=1.5418 \AA$ at $40 \mathrm{kV}$ and 40 $\mathrm{mA}$, over the range of $2 \theta=0-40^{\circ}$. Fourier transform infrared (FTIR) analysis of the samples was performed with a Perkin-Elmer Spectrum GX FT-IR Spectrometer using $\mathrm{KBr}$ discs, in the range $4000-400 \mathrm{~cm}^{-1}$. The surface area of the sample was determined by Quantachrome Autosorb-1 at $77 \mathrm{~K}$. Prior to the measurement, the sample was outgassed at $573 \mathrm{~K}$ for $3 \mathrm{~h}$. 


\subsection{Pyridine adsorption procedure}

Figure 1 illustrates the schematic diagram of gas flow-injection technique for adsorption of pyridine on solid material. The adsorption procedures are as follows. A self-supported wafer placed in an in-situ stainless steel cell IR cell with $\mathrm{CaF}_{2}$ windows was heated in a nitrogen gas flow at $623 \mathrm{~K}$ for $3 \mathrm{~h}$. Then, the sample was exposed to the pyridine at $423 \mathrm{~K}$ for $1 \mathrm{~h}$ followed by flushing of nitrogen gas at $573 \mathrm{~K}$ for $30 \mathrm{~min}$. Nitrogen gas was dried by molecular sieve and double liquid-nitrogen traps. All spectra were recorded at room temperature.

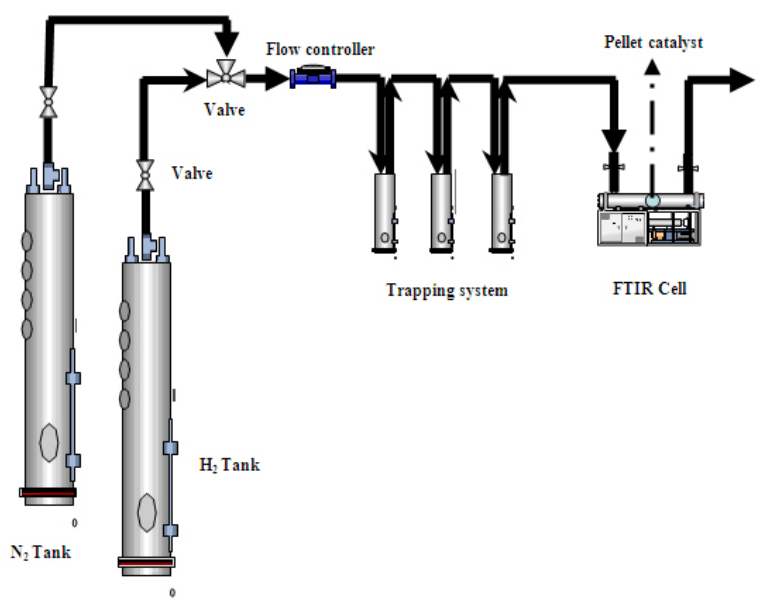

Fig. 1 : Schematic diagram of gas flow-injection technique.

\section{RESULTS \& DISCUSSION}

\subsection{Characterization of the catalyst}

The specific surface area of HZSM-5, $\mathrm{Pt} / \mathrm{SO}_{4}{ }^{2-}-\mathrm{ZrO}_{2}$, $\mathrm{Al}_{2} \mathrm{O}_{3}$ catalysts were 345,110 and $190 \mathrm{~m}^{2} / \mathrm{g}$, respectively. The diffractogram of HZSM-5 is shown in Figure 2. The XRD result indicated the high crystallinity of the sample. Significant peaks which corresponding to the specific peaks of ZSM-5 was observed in the range of $2 \theta=7-10^{\circ}$ and 22$25^{\circ}[10]$. Figure 3 shows the XRD pattern of $\mathrm{Pt} / \mathrm{SO}_{4}{ }^{2-}-\mathrm{ZrO}_{2}$ (PSZ). The PSZ sample displayed two well-established polymorphs of monoclinic and tetragonal phases. The peak at about $2 \theta=30^{\circ}$ is assigned to tetragonal phase of zirconia, and the peaks at about $2 \theta=28^{\circ}, 32^{\circ}$, and $35^{\circ}$ are assigned to monoclinic phase of zirconia. The peaks at about $2 \theta=40^{\circ}$ and $2 \theta=45^{\circ}$ corresponding to $\mathrm{Pt}(111)$ and $\mathrm{Pt}(200)$ are not observed which indicated that the amount of Pt is too small for mass analysis [11]. Although it is not shown here, the amorphous structure was observed for $\mathrm{Al}_{2} \mathrm{O}_{3}$ sample.

Figure 4 presents the FTIR spectrum of HZSM-5. Significant absorption bands are observed at 1225, 1100, 795,545 and $450 \mathrm{~cm}^{-1}$. Absorption bands at 1225 and 1100 $\mathrm{cm}^{-1}$ are corresponding to the external and internal asymmetric stretching vibration of $\mathrm{TO}_{4}$ tetrahedral respectively. The absorption band at $795 \mathrm{~cm}^{-1}$ is assigned to the external symmetric stretching vibration while the band observed at $545 \mathrm{~cm}^{-1}$ indicated the vibration of double five member-rings by tetrahedral $\mathrm{SiO}_{4}$ and $\mathrm{AlO}_{4}$ units. The 450 $\mathrm{cm}^{-1}$ absorption band is attributed to internal vibration of $\mathrm{Si}$ and $\mathrm{AlO}_{4}$ tetrahedral. The existence of bands at 450, 545, 795, 1100 and $1225 \mathrm{~cm}^{-1}$ are indicating the complete crystalline structure of ZSM-5 which is parallel to the XRD results [10].

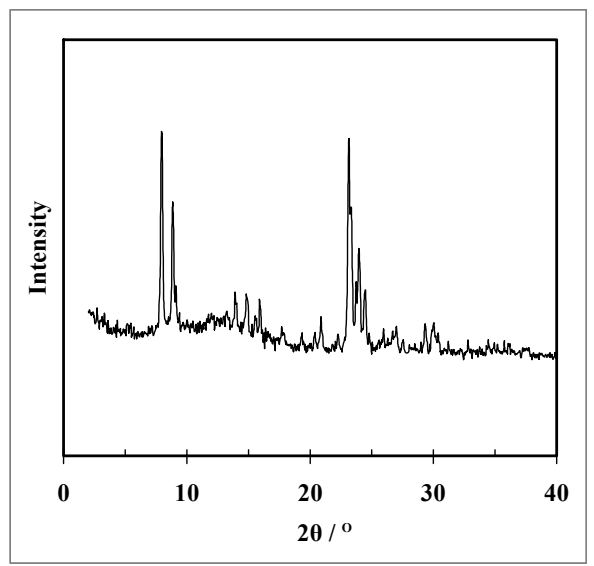

Fig. 2 : XRD pattern of HZSM-5.

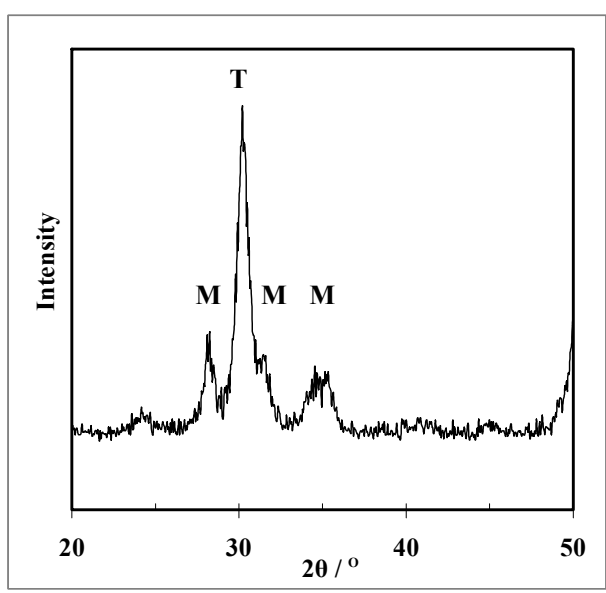

Fig. 3 : XRD pattern of $\mathrm{Pt} / \mathrm{SO}_{4}{ }^{2-}-\mathrm{ZrO}_{2}$.

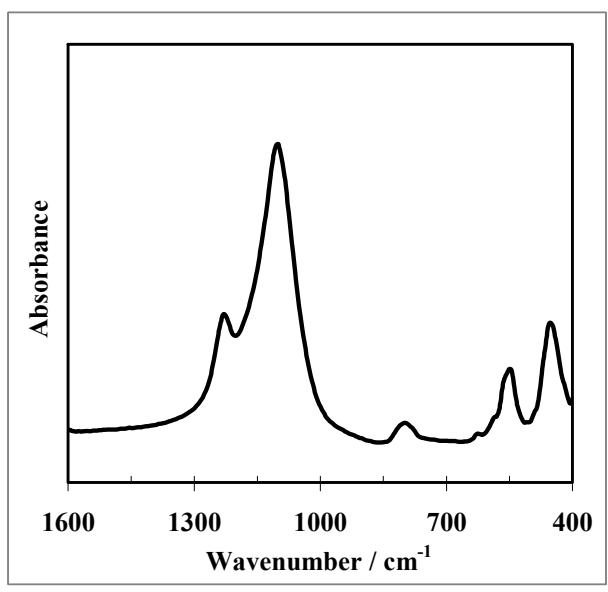

Fig. 4 : FTIR spectrum of HZSM-5. 
FTIR spectrum of PSZ is displayed in Figure 5. The sample showed a strong peak at $1395 \mathrm{~cm}^{-1}$ which is assigned to the asymmetric $\mathrm{S}=\mathrm{O}$ stretching mode of sulfated groups bound by bridging oxygen atoms to the surface. Two other bands at 1025 and $1040 \mathrm{~cm}^{-1}$ are assigned to the asymmetric stretching frequencies of the S-O bonds [12].

\subsection{The acidity of sample}

Figure 6 shows the spectra of adsorbed pyridine on HZSM-5 measured by vacuum and flow techniques. The absorption bands at 1455,1545 and $1490 \mathrm{~cm}^{-1}$ are due to pyridine adsorbed on Lewis acid site (L:Py), Brönsted acid site (B:Py), and on both acid sites $((\mathrm{B}+\mathrm{L}): \mathrm{Py})[13]$. The result clearly revealed the similarity of the results measured by vacuum and flow techniques.

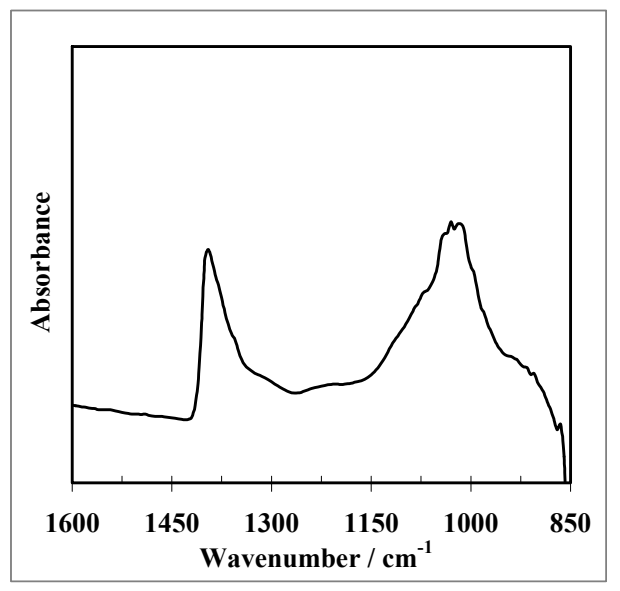

Fig. 5 : FTIR spectrum of $\mathrm{Pt} / \mathrm{SO}_{4}{ }^{2-}-\mathrm{ZrO}_{2}$.
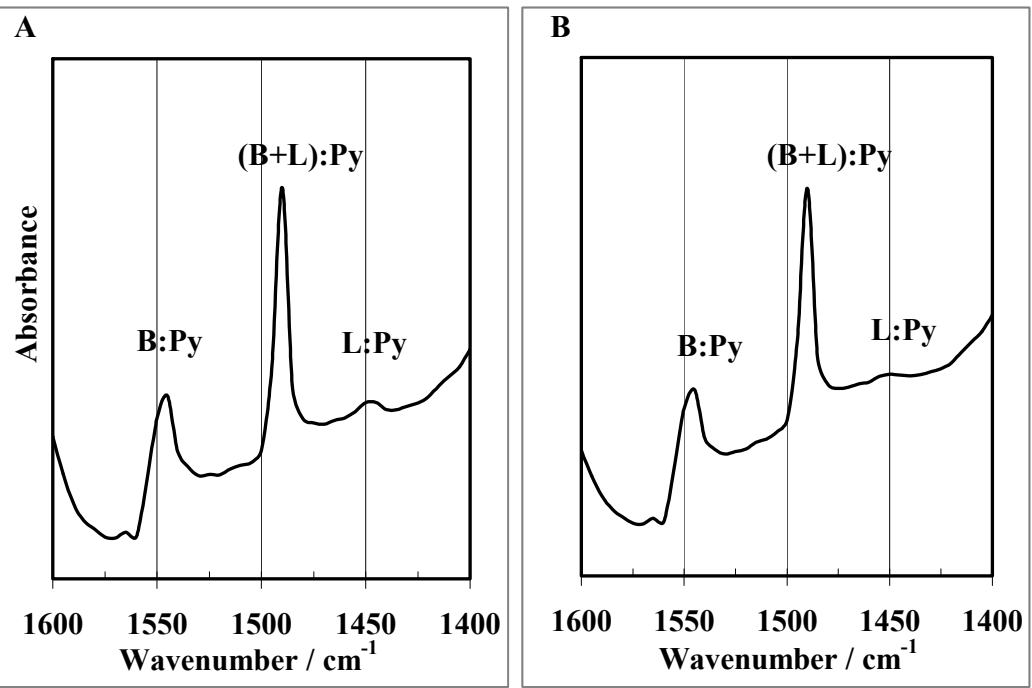

Fig. 6 : IR spectra of pyridine adsorbed on Zn/HZSM-5 for (A) vacuum system and (B) flow system.
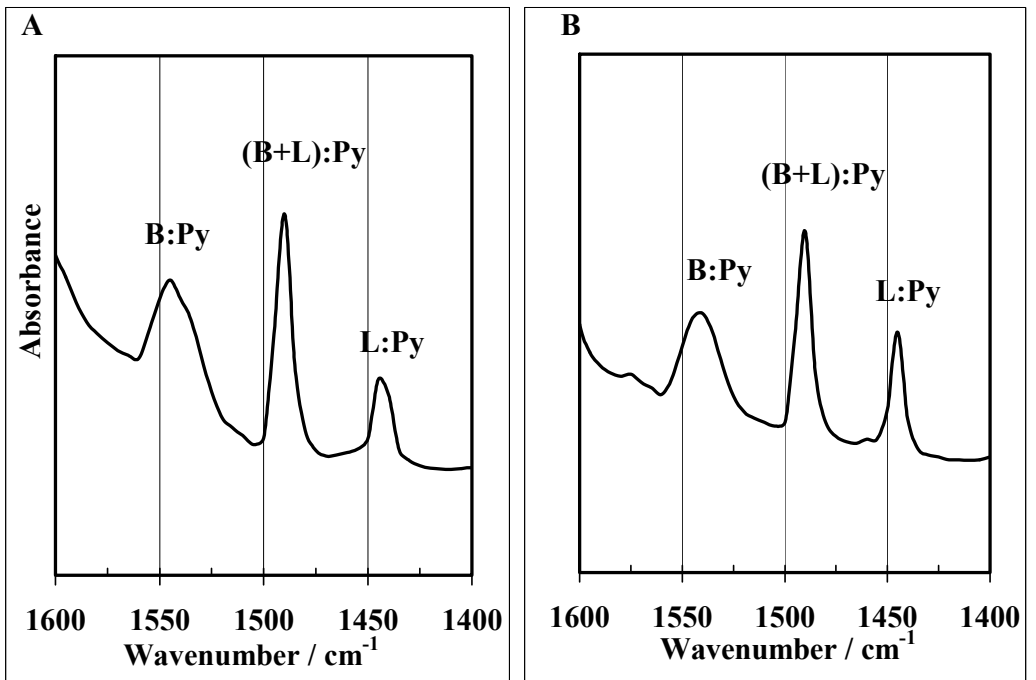

Fig. 7 : IR spectra of pyridine adsorbed on $\mathrm{Pt}_{\mathrm{SO}} \mathrm{SO}_{4}{ }^{2-}-\mathrm{ZrO}_{2}$ for (A) vacuum system and (B) flow system 
Table 1: Acid sites fraction of HZSM-5.

\begin{tabular}{lcccc}
\hline \multirow{2}{*}{ Catalysts } & \multicolumn{3}{c}{ Vacuum system } & \multicolumn{2}{c}{ Flow system } \\
\cline { 2 - 5 } & \multicolumn{4}{c}{ Fraction of acid sites } \\
\cline { 2 - 5 } & Brönsted & Lewis & Brönsted & Lewis \\
\hline $\begin{array}{l}\text { HZSM-5 } \\
(\mathrm{Si} / \mathrm{Al}=80)\end{array}$ & 0.89 & 0.11 & 0.92 & 0.08 \\
$\begin{array}{l}\mathrm{HZSM}-5 \\
(\mathrm{Si} / \mathrm{Al}=90)[14]\end{array}$ & 0.9 & 0.1 & - & - \\
$\begin{array}{l}\mathrm{HZSM}-5 \\
(\mathrm{Si} / \mathrm{Al}=49)[15]\end{array}$ & 0.72 & 0.28 & - & - \\
$\begin{array}{l}\mathrm{HZSM}-5 \\
(\mathrm{Si} / \mathrm{Al}=37)[16]\end{array}$ & 0.69 & 0.31 & - & - \\
\hline
\end{tabular}

More obvious observation would be found by calculating the fraction of acid sites on solid acid catalyst. The fraction of acid sites on solid catalysts can be estimated by method described in the literature [14]. The fraction of Brönsted and Lewis acid sites of the sample measured by vacuum technique are 0.89 and 0.11 , while those measured by flow technique are 0.92 and 0.08 respectively. The results gave a good agreement with previous report by Takahara et al. [14]. They estimated the fraction of Brönsted and Lewis acid sites of HZSM-5 were 0.9 and 0.1 . However, several papers pointed out the different value of fraction of acid sites on HZSM-5 as described in Table 1 [15-17]. The differences may be caused by the difference of silica alumina ratio of HZSM-5. On the rising of silica alumina ratio, the fraction of Brönsted acid sites rose while the fraction of Lewis acid sites decreased. It can be due to a higher stability of HZSM-5 as the silica alumina ratio increases, which hinders the dehydroxylation of Brönsted acid sites [14].

The spectra of adsorbed pyridine on PSZ measured by vacuum and flow techniques are showed in Figure 7. The results showed that there are no significant differences on the Lewis and Brönsted acid site peaks for both techniques. The fraction of Brönsted and Lewis acid sites of PSZ measured by vacuum technique are 0.55 and 0.45 , while those measured by flow technique are 0.44 and 0.56 . The values are close to those reported by Stevens et al. [8] which the fraction of Brönsted and Lewis acid sites of PSZ are 0.46 and 0.54 , respectively. However, other researchers [18-19] reported the different values for fraction of acid sites of PSZ as described in Table 2. The differences may be influenced by the differences in the evacuation temperature and/or time. By increasing the evacuation temperature and/or time, pyridine molecules adsorbed on weak acid sites should be desorbed while those adsorbed on strong acid sites could be retained. The PSZ results in this experiment indicated that Lewis acid sites are strong enough to retain pyridine against evacuation at high temperature, while there is a considerable number of weak Brönsted acid sites from which adsorbed pyridine is desorbed by evacuation at high temperature. Therefore the fraction Brönsted acid sites drastically decreased as the evacuation temperature was raised [5].
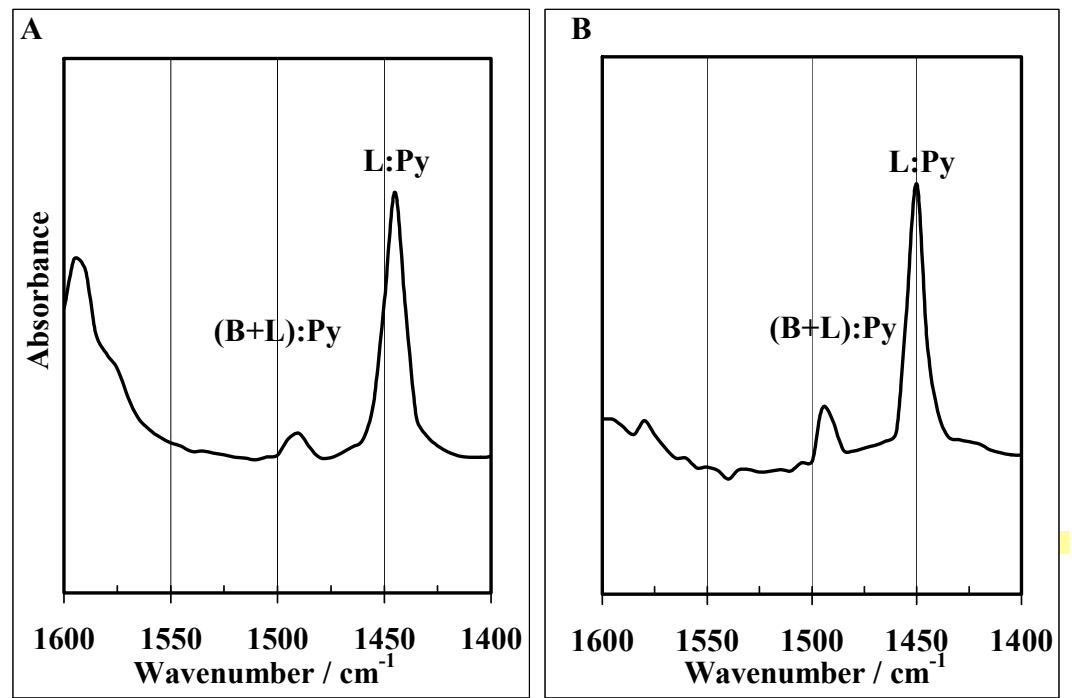

Fig. 8 : IR spectra of pyridine adsorbed on $\mathrm{Al}_{2} \mathrm{O}_{3}$ for (A) vacuum system and (B) flow system.

The extinction coefficient ratio of Brönsted to Lewis acid sites for HZSM-5 and PSZ were 1.49 and 1.69 respectively. The ratio of extinction coefficient at bands 1454 and $1545 \mathrm{~cm}^{-1}$ was determined by converting the bands at $1454 \mathrm{~cm}^{-1}$ to the band at $1545 \mathrm{~cm}^{-1}$ by addition of a small quantity of water. The obtained value is different with our previous report for $\mathrm{HZSM}-5$ and $\mathrm{Pt} / \mathrm{WO}_{3}-\mathrm{ZrO}_{2}$ which the extinction coefficient of ratio were 1.1 and 1.82 respectively $[5,15]$. This difference may be resulted by the differences between the integrated absorbance and the absorbance at the peak position.

We have also applied gas flow-injection technique for pyridine adsorption FTIR to measure the acidity of $\mathrm{Al}_{2} \mathrm{O}_{3}$ (AKP50 Sumitomo Chemical Co., Japan). Figure 8 
reveals the spectra of adsorbed pyridine on $\mathrm{Al}_{2} \mathrm{O}_{3}$ measured by vacuum and flow techniques. As can be seen, both techniques provide alike results which have a great intensity of Lewis acid site with the absence of Brönsted acid site. The intensity ratio of absorption bands at 1455 and 1490 $\mathrm{cm}^{-1}$ are 5.38 and 4.71 for vacuum and flow techniques, respectively. The similar values were also reported in several literatures [19-20].

Table 2 : Acid sites fraction of $\mathrm{Pt} / \mathrm{SO}_{4}{ }^{2-}-\mathrm{ZrO}_{2}$.

\begin{tabular}{|c|c|c|c|c|c|}
\hline \multirow{3}{*}{ Catalysts } & \multirow{3}{*}{$\begin{array}{c}\text { Temperature } \\
\text { of } \\
\text { Evacuation / } \\
\mathrm{K}\end{array}$} & Vacuum & ystem & Flow sy & tem \\
\hline & & & action of a & acid sites & \\
\hline & & Brönsted & Lewis & Brönsted & Lewis \\
\hline$\overline{\mathrm{PSZ}}$ & 523 & 0.55 & 0.45 & 0.44 & 0.56 \\
\hline PSZ [8] & 423 & - & - & 0.46 & 0.54 \\
\hline PSZ [18-19] & 673 & 0.28 & 0.74 & - & - \\
\hline
\end{tabular}

Based on the results of HZSM-5, PSZ and $\mathrm{Al}_{2} \mathrm{O}_{3}$, the gas flow-injection technique was acceptable technique for determination of acidic sites of solid materials.
Furthermore, this technique gives important advantages as compared to vacuum system, such as simple apparatus, easy in handling, and short time analysis.

\section{CONCLUSION}

Gas flow-injection technique pyridine FTIR was developed to determine Lewis and Brönsted Acid sites of solid catalysts. This technique gave a similar results with the results measured by conventional vacuum technique. This technique gives several advantages such as simple apparatus, short time analysis and easy in handling and experiment.

\section{ACKNOWLEDGEMENT}

This work was supported by the Ministry of Science, Technology and Innovation, Malaysia (MOSTI) under EScience Fund Research Project No. 03-01-06-SF0020 and No. 03-01-06-SF0564.

\section{REFERENCES}

[1] G. Busca, Chemical Reviews, 2007, Vol. 107, No 11.

[2] G.V.A. Martins, G. Berlier, C. Bisio, S. Coluccia, H.O. Pastore, and L. Marchese, Jornal of Physical Chemistry C, 2008, 112, 7193-7200.

[3] N. Keller, G. Koehl, F. Garin, and V. Keller, Chemical Communication, 2005, 201-203.

[4] A. Platon and W.J. Thomson, Industrial and Engineering Chemistry Research, 2003, 42, 5988-5992.

[5] S. Triwahyono, T. Yamada, H. Hattori, Applied Catalysis A: General 242 (2003) 101-109.

[6] S. Triwahyono, T. Yamada, H. Hattori, Applied Catalysis A: General 250 (2003) 75-81.

[7] J. Ryczkowski, Catalysis Today, 68 (2001) 263-381.

[8] R.W. Stevens Jr, S.S.C. Chuang, and B.H. Davis, Applied Catalysis A: General 252 (2003) 54-74

[9] R. Olindo, A. Goeppert, D. Habermacher, J Sommer, and F. Pinna, Journal of Catalysis, 197, $344-349$ (2001).

[10] Y. Tao, H. Kanoh, and K. Kaneko, Journal of American Chemical Society, 2003, 125, 6044-6055.

[11] S. Triwahyono, Aishah A.J., Halimaton, H., Journal-The Institution of Engineers, Malaysia (vol.67, No 1, 2006).

[12] P. Wang, S. Yang, J.N. Kondo, K. Domen, T. Yamada, and H. Hattori, Journal of Physical Chemistry B, 2003, 107, 11951-11959.

[13] T.R. Hughes, H.M. White, Journal of Physical. Chemistry, 71 (1967) 2192.

[14] I. Takahara, M. Saito, M. Inaba, and K. Murata, Catalysis Letters, Vol. 105, Nos. 3-4, 2005.

[15] K. Ebitani, J. Tsuji, H. Hattori, and H. Kita, journal of Catalysis, 138, 750-753 (1992).

[16] H. Matsuura, N. Katada, and M. Niwa, Microporous and Mesoporous Materials, 66 (2003) 283-296.

[17] A. Zhang, I. Nakamura, and K. Fujimoto, Journal of Catalysis 168, 328-333 (1997).

[18] K. Ebitani, J. Tsuji, H. Hattori, and H. Kita, journal of Catalysis, 135, 609-617 (1992).

[19] S. Triwahyono, T. Yamada, and H. Hattori, Catalysis Letter, Vol. 85, Nos. 1-2, 2003.

[20] Z. Sarbak, Applied Catalysis A: general 159 (1997) 147-157.

[21] G. Crpeau, V. Montouillout, A. Vimont, L. Mariey, T. Cseri, and F. Maug, Journal of Physical Chemistry B, 2006, 110 (31), $15172-15185$. 